\begin{tabular}{|l|l|l||}
\hline \multicolumn{2}{|c|}{ PublisherInfo } \\
\hline \hline PublisherName & $:$ & BioMed Central \\
\hline \hline PublisherLocation & $:$ & London \\
\hline \hline PublisherImprintName & $:$ & BioMed Central \\
\hline \hline
\end{tabular}

\title{
Possible target for male contraception
}

\begin{tabular}{|l|l|l||}
\hline \multicolumn{2}{|c|}{ ArticleInfo } \\
\hline \hline ArticleID & $:$ & 3893 \\
\hline \hline ArticleDOI & $:$ & $10.1186 /$ gb-2001-2-11-reports0040 \\
\hline \hline ArticleCitationID & $:$ & reports0040 \\
\hline \hline ArticleSequenceNumber & $:$ & 18 \\
\hline \hline ArticleCategory & $:$ & Paper report \\
\hline \hline ArticleFirstPage & $:$ & 1 \\
\hline \hline ArticleLastPage & $:$ & 3 \\
\hline \hline & & \\
\hline ArticleHistory & $:$ & Received $\quad: \quad 2001-8-21$ \\
& & OnlineDate $\quad$ 2001-10-26 \\
\hline \hline ArticleCopyright & $:$ & BioMed Central Ltd2001 \\
\hline \hline ArticleGrants & $:$ & \\
\hline \hline
\end{tabular}




\begin{tabular}{|l|l|l|l|}
\hline ArticleContext & $:$ & 13059221111 \\
\hline
\end{tabular}

\section{John C Rockett}

\section{Abstract}

A human sperm-specific protein has been isolated that may prove useful in the development of a contraceptive vaccine.

\section{Significance and context}

Contraception has always been an important area of reproductive biology research, and there are ongoing efforts to develop less expensive, more efficient and more easily administered methods. Immunocontraceptives have received much attention, not only for their long- or short-term application in both human sexes, but also as a possible means of 'humane' wildlife population management for species such as white-tailed deer, coyotes and other economically important or pest species. Ideal targets for vaccines are gamete-specific, and here Santhanam and Naz describe the isolation and initial characterization of a human cDNA, designated TSA-1, that appears to be expressed only in testis and sperm.

\section{Key results}

The authors demonstrated that TSA-1 mRNA does not seem to be expressed in any of 18 major organs and tissues other than the testis. The protein product is expressed at several points along the surface of mature human spermatozoa, predominantly at the acrosomal, equatorial, mid-piece and tail regions of capacitated and non-capacitated cells. When human spermatozoa were incubated in the presence of antiTSA antibody during (artificially induced) sperm capacitation (which is required for oocyte fertilization), there was a significant inhibition of the acrosome reaction at antibody concentrations of 40 $\mu \mathrm{g} / \mathrm{ml}$ (61\% inhibition) and $85 \mu \mathrm{g} / \mathrm{ml}$ (75\% inhibition), compared with $26 \%$ inhibition in the controls.

\section{Reporter's comments}

Although the human genome has apparently been sequenced, the function and spatial and temporal expression of most of the genes still awaits characterization. In this context, the discovery of 'new' genes 
is the domain of open differential expression techniques such as differential display, which, unlike DNA arrays, are not limited to analyzing the expression of a defined set of genes but instead are capable of selecting any gene (known or unknown) that is differentially expressed between two tissues or between a control and treated model. Santhanam and Naz thus used this approach to isolate a 'testis-specific' gene, although whether this is truly testis-specific will need to be more thoroughly addressed if TSA is carried forward as a potential immunocontraceptive. Ten different tissues were examined for TSA-1 mRNA expression using RT-PCR and Southern blot, and a further eight using northern blots. Unfortunately, northern blots are not very sensitive and there has been more than one report of negative expression in northerns becoming positive when RT-PCR analysis was applied. Furthermore, there are many more cells and tissues in the body than the 18 that were examined, and as the RNA from these tissues was obtained from normal healthy adults it does not take into account RNA expression in, for example, diseased or damaged organs. Nevertheless, the results suggest that TSA is indeed likely to be testis-specific, and the authors subsequently confirmed that the protein product is expressed on human sperm. Unfortunately, no evidence was presented indicating whether TSA protein is sperm-specific (as opposed to testis-specific) and, if so, at what stage of spermatogenesis the protein is first expressed. But the fact that this protein appears to be surface-expressed over much of the mature sperm cell suggests that further investigation into its immunocontraceptive potential would be worthwhile. TSA will also be valuable in isolating the homologs (if they exist) in laboratory and wild species of particular organisms in order to examine the extent of cross-species conservation and the possibility of its application to population control in such species.

\section{Table of links}

Molecular Reproduction and Development

\section{References}

1. Santhanam R, Naz RK: Novel human testis-specific cDNA: molecular cloning, expression andimmunobiological effects of the recombinant protein. Mol Reprod Dev. 2001, 60: 1-12. 1040-452X 